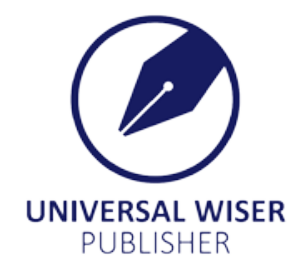

\title{
Business Cycle Drivers in an Open Economy
}

\author{
Oluremi Ogun \\ University of Ibadan, Nigeria \\ E-mail: 1rogun@gmail.com
}

\begin{abstract}
In this paper, an investigation into the sources of business cycles in Nigeria over the period, 1960-2013, was conducted. Nigeria was a lower middle income economy that pursued open economy policies. The propositions tested in the study cut across most of the schools of thought prominent in the subject area. All policies/factors examined were assumed to generate cycles that were subsequently tested for causal relations with the cycles of domestic output and industrial productions. The causality approach adopted for the analysis was of the Granger type. Detrending of the various data series was undertaken using two filters. Unit root tests were conducted to assure integration of the cyclical components of detrended series. In the final analysis, only monetary policy cycles and cycles linked to exogenous shocks of different varieties credibly drove the cycles of domestic output and industrial productions in the country. A rule-based monetary policy in a conservative fiscal environment emerged as favourite.
\end{abstract}

Keywords: business fluctuations and cycles, monetary policy, central banks and their policies, policy objectives, policy design and consistency, policy coordination, comparative or joint analysis of fiscal and monetary policy, stabilization, treasury policy

\section{Introduction}

Depending on its nature, business cycle often generated significant fluctuations in economic activities that on the downside could translate into output declines and marked unemployment. Being accepted as inevitable in market/capitalist economies, the focus of policy was not usually to avert its occurrence, rather, to minimize the frequency of occurrence and allied output losses. In the literature, most studies of business cycle had been on the developed industrial countries with little attention paid to its occurrence and dimensions in the developing world. As some developing economies were large and open, developments therein could produce spill over effects on other countries. Hence, a study of business cycles in such economies could significantly help our understanding of their growth dynamics as well as the damage control policies necessary to reduce the duration of recession and elongate expansion.

The aim in this study therefore was to investigate the sources of business cycles in an open and lower middle income economy, Nigeria, with gross domestic income per capita (at constant 2010 US prices) of about US $\$ 2,362$ in $2013^{[1]}$. Being a developing economy, short run goal ambitions could promote uncontrolled growth of policy instruments. In this study, propositions of relevant business cycle theories were tested using the country's data. For proper anchor, the question that guided the investigation in the study was, could cycles in particular types of policies or exogenous occurrences explain cycles in domestic output? [1 For an insight into the generalized nature and sources of output fluctuations in developing economies, see for example the section on linked literature in Ogun ${ }^{[3]}$.] The analysis covered the period 1960-2013 with occasional references to the more distant past.

The rest of the paper is organized as follows. Section 2 provides a brief review of linked literature. Section 3 discusses the framework and methodology of the study and also presents the preliminary data analysis. In section 4 , the results are discussed. Section 5 concludes the study with the policy implications.

\section{Theories of business cycle}

Prominent modern theories of business cycle in the literature comprised the Classical theory, the Monetarist theory, the New Classical School (NCS), the Keynesian theory and its variants notably, the New Keynesian School (NKS).

A standard classical business cycle model was embodied in the propositions by Kydland and Prescott ${ }^{[2]}$. The 
assumptions driving the classical business cycle fluctuations included: an infinitely large number of identical households that took decisions on consumption, investment and labour supply over time; the representative household faced a budget constraint, and capital accumulation constraint; firms maximized profit subject to budget constraints; both firms and households operated within a competitive market system where prices were assumed to be given, and, the economy was of the one-good closed type without government. The only source of fluctuation in this standard business cycle model was technology shocks.

The classical business cycle predicted that in equilibrium, the household's decision functions were optimal given the price functions and the law of motion for per capita stock; the firm's decisions were optimal given the pricing function; market clearing conditions were satisfied in all markets: labour, capital and goods; and rational expectations maintained. Kydland and Prescott ${ }^{[2]}$ proposed a methodology that could be used to approximate these decision functions. The standard classical business cycle model was applied to post World War II quarterly data of the US economy and the results suggested that the model could account for much of the observed variability in output, investment and capital stock. According to this school of thought with automatic-correcting forces, there would be no deviation from the path of natural real GDP growth. In this manner, there was no business cycle and unemployment was a transitory phenomenon with inbuilt stabilizer. Unemployment occurred because of the prevailing inflexibility of wages and not because fiscal and monetary policy were not adopted by government. This class of business cycle model had come to be known as the Real Business Cycle (RBC).

The shortcomings of this model had been mostly associated with its underlying assumptions. Generally, a world with only one form of shocks, no nominal frictions, and absence of government, perfect competition and autarky situation was unimaginable. Summers ${ }^{[4]}$ raised four shortcomings on the RBC. First, the working parameters used in the model could not be tied securely to the growth and micro-economic observations of the model; the parameters used by Prescott including the share of household time allocated to market activities, average real interest rate taken as $4 \%$ and intertemporal elasticity of substitution, were arbitrarily assumed and difficult to support in reality.

Secondly, Summers observed that in Prescott's model, the central driving force behind cyclical fluctuation was technological shock and the propagation mechanism was intertemporal substitution in employment; independent evidence in support of either of these phenomena was lacking. Thirdly, the Prescott's argument that carried out a price-free economic analysis was defective in that, price and price mechanism were major cornerstones in economic analysis. In Summers' opinion, it was hard to understand how economic model could be said to have been tested without price data.

Lastly, Summers was convinced that exchange failure was responsible for the great depression between 1929 and 1933 in the USA. At that period, firms had output that they wanted to sell and workers wanted to exchange their labour for it, but exchange did not take place. And this ought not to have been ignored as did Prescott in his model. According to Summers, "a model that embodied exchange was a minimum prerequisite for a serious theory of economic downturn". He objected to situations whereby particular phenomenon such as exchange failure was ignored simply because we did not yet fully understand it.

The monetarist school provided an alternative to the Keynesian assumptions of nominal wage rigidity and non-market clearing in order to explain the existence of business cycles. The reference point was Friedman "fooling" model ${ }^{[5]}$. In this model, it was postulated that labour supply curve was dependent on expected real wage, $w / p^{e}$, rather than the actual real wage, $\mathrm{w} / \mathrm{p}$. The implication of this was that the presence of imperfect price information on the part of workers would allow the economy to deviate from the long-run natural level of output and thus generated business cycles. The Friedman model was an important development in modern business cycle theories.

An aspect of monetarist theory emphasizing the importance of the money stock or changes on business cycles had not been deemed entirely satisfactory as reverse causation remained a real possibility and doubts existed as to whether the action of the monetary authorities could actually explain output fluctuations. However, econometrics informed that in the former case, convincing evidence could be obtained through logarithmic estimates while in the latter, credibility had been restored to monetary policy via the notion of exogeneity, that is, when the policy action was as a result of an independent event or motive that was unconnected with the state of the economy. Friedman and Schwartz ${ }^{[6]}$ provided many instances of such exogenous policy making and their output effects in the case of the United States. In effect, monetary policy will affect short run output growth [2 see also, Jahan and Papageorgiou $\left.{ }^{[7]}\right]$. In addition, over time, the real interest rate angle had been found to hold some explanations on output fluctuations.

The basic tenet of the New Classical School of thought was the policy ineffectiveness proposition (PIP) in which it was postulated that no systematic stabilization policy (fiscal or monetary) had any real influence on the economy, except on nominal variable. According to them, policy could only have a real effect if it was unanticipated. Their methodology 
was built on the tradition of sophisticated mathematical general equilibrium model in which all individual economic agents were assumed to be rationally optimizing. And this was the approach encountered in the standard classical business cycle theory.

The New Classical model was built around certain assumptions including the Friedman's market-clearing ${ }^{[5]}$, imperfect information as well as the assumption of rational expectations. The latter was based on the belief that people made their best forecasts of the future based on all available information rather than having to learn and catch up with the current situation. In rational expectations models, individuals were forward-looking and they adjusted their expectations to their best forecasts of the future; errors in expectations occurred only randomly and independently. What was important to business cycle theory was the behavior of the supply curve. In this respect, a distinction was generally made between local and aggregate supply curve.

In effect, an individual would be willing to supply more if the price of his/her product rose relative to the general price level. In this case, it was assumed that individual knew the price of own product but as a result of information asymmetry could not directly observe the price of other products. Consequently, once there was any price change, the individual must infer whether it was a local or an aggregate price shock. Given the possibility of individuals making incorrect guesses, the economy was bound to deviate from the natural level of GDP and generated business cycle.

The Keynesian revolution was a major intellectual response to the Great Depression (GD) of the 1930s. From theoretical standpoint, the Keynesian critique of the classical auto-correcting mechanism rested on two axes. First, was the failure of demand to adjust because of deflation or weakness of demand, that is, inability of real GDP to respond to an increase in the real money supply or a fall in the real interest rate? Second, the failure of supply to adjust as a result of rigid wages, that is, inability of the nominal wage rate to adjust by the amount needed to maintain equilibrium in the labour market. This school postulated that unemployment was caused by weak demand. To them, therefore, business cycle was caused by suboptimal price adjustment following the shock.

Using the IS-LM apparatus, to analyze aggregate demand (AD) and aggregate supply (AS), the Keynesians assumed that, not all prices were flexible, existence of money illusion and distribution effects as well as inelastic price expectations. In this line of argument, nominal wage rigidity and non-market clearing assumptions were critical. According to Reside Jr. (2002), the standard AD-AS model interpreted aggregate demand shocks as emanating from autonomous changes in the money supply, government spending, investment and consumption. Aggregate supply shocks emanated from changes in productivity with short-run and long-run effects on output. These were associated with permanent shocks. Similarly, the AD shocks had short-run effects and they were neutral with respect to output in the long-run. Thus, AD shocks were interpreted as temporary or transitory shocks.

In response to business cycle fluctuations, the Keynesians proposed government intervention in order to stabilize aggregate demand and thereby minimize the negative effects of the welfare loss inherent in business cycle fluctuations and that could instigate social disequilibria. However, the major shortcoming of this school of thought was the inability of the model to incorporate dynamic effects, rational expectations and microeconomic foundation criteria to support their position. According to the Keynesians, business cycles were results of failure of the economic system due to frictions or market imperfections. Consequently, the economy experienced depressions and failed to achieve the efficient level of output and employment. In their postulations, financial frictions, sticky prices and other adjustment failures constituted the propagation mechanism. Thus, both technology and monetary shocks were considered to be important sources of fluctuations.

In terms of business cycle research, the Keynesians would normally introduce their beliefs in government intervention in order to stabilize the seemingly costly business cycle fluctuations. A reference point for illustrating this was the model due to McGrattan ${ }^{[8]}$. The essence was to reconcile the shortcomings observed in the classical business cycle model once fiscal shocks were included in the model. Thus, the theoretical base remained the growth theory. However, the main difference between the original classical model and the McGrattan " ${ }^{[8]}$ "Keynesian" model resulted from varying the assumptions of the model. In effect, the representative household preference in the "Keynesian" model was made dependent on government consumption, and divisible labour. The household budget constraint became influenced by tax payments and government transfers. Quite apart from the only technology shock (supply side shock), this approach contained additional shocks notably government consumption, tax rate on capital and tax rate on labour. All other assumptions adduced to in the standard classical business cycle model remained unchanged.

In general, following ${ }^{[8]}$, the model predicted that in equilibrium, the household decision functions were optimal given the pricing function, the law of motion for per capita capital stock, and the government transfer function; the firm's decision were optimal given the pricing functions; government satisfied its budget constraint per period; market clearing 
condition satisfied for labour, capital and goods, and, expectations were rational and sustained.

The philosophical foundation of the New-Keynesian (NK) was rooted in the Keynesian mainstream. However, its main difference lied in the methodological approach to analyzing business cycle phenomenon. It assumed the existence of (1) involuntary unemployment (2) monetary non-neutrality and (3) short-run inflexibility of wages and prices. The proponents of this school relied on sticky wages and prices to explain the existence of involuntary unemployment and why monetary policy was non-neutral on economic activities. Gordon ${ }^{[9]}$ provided a coherent theoretical explanation for the sluggish behavior of prices and these included menu costs and aggregate-demand externalities: prices did not adjust spontaneously to clear market because information was costly; the presence of staggering prices phenomenon; possibility of coordination failure resulting into recession; and presence of efficiency wage theory which was defined as a function of the wage received.

The theoretical model of NK was based on rational expectations and microeconomic foundation and usually summarized in three equations that depicted the optimizing behavior of economic agents in the economy. These were the aggregate demand curve or the traditional Keynesian IS curve; the aggregate supply which took the form of money demand relationships; and forward-looking version of the Phillips curve. In general, NKS characterized the dynamic behavior of output, inflation and nominal interest rate. Its proponents however believed that other shocks might be important and in particular that the presence of nominal price rigidities helped determine exactly how shocks of all kinds impacted on and propagated through the economy. [3 For an elaboration on the workings of different types of nominal rigidities, see for example Knotec ${ }^{[10]}$.]

\section{Analytical framework, methodology and preliminary data analysis}

This study was conducted within the context of business cycle drivers. Essentially, it was a macro study of economic fluctuations cutting across monetary, fiscal, trade and external sector linked issues, technological changes as well as strictly exogenous (or world economic) factors. Accordingly, the propositions tested in the study covered the potency of monetary factors ${ }^{[6,11,12]}$, fiscal factors ${ }^{[12,8]}$, trade/external sector linked factors ${ }^{[13]}$, technology shocks ${ }^{[14,15]}$, and, exogeneity ${ }^{[6,16]}$. $[\mathrm{By}$ implication, the examination of the propositions from trade/external sector linked factors and exogeneity in the external economy context in this study appeared to have extended the theories of business cycle reviewed in section 2 beyond their original closed economy framework.] In order to properly anchor the analysis within this framework, the prime question posed in the study was, could cycles in particular types of policies or exogenous occurrences explain cycles in domestic output? A bivariate causality analysis was deployed to handle this question. The causality analysis followed Granger ${ }^{[17]}$ that could be simply represented as:

1) $Y_{t}=Y\left(Y_{t-i}, X_{t-i}\right)$

Where, $Y_{t}$ is the current or predicted value of variable $Y, Y_{t-i}$ are its lagged values and $X_{t-i}$ are the lagged values of the exogenous variable $X$. In this expression, $Y$ is said to be Granger-caused by $X$ if $X$ helps to predict $Y$ or the coefficients on the lagged $X s$ are statistically significant.

Causality approach is an atheoretical method in which expectation of result would be reflected in the alternative hypothesis. The data employed in the analysis were obtained from various sources; both the data and sources would be made available upon request.

Detrending of the various series was undertaken using the Baxter-King's band-pass (BP) and Hodrick-Prescott (HP) filters. The idea was to generate the cyclical components of the series which were expected to be stationary. The unit root tests conducted according to both the Augmented Dickey-Fuller (ADF) and the Phillips-Perron (PP) procedures and presented in Table 1 showed the series as generally stationary at level. The only noticeable problem cases were the monetary aggregates, M1 and M2, under which the BP filters strongly suggested integration at the second difference while the HP equivalent recorded them as I(0). Also, the cycle corresponding to fitted income series was I(0) by ADF but I(2) under PP. Foreign income was only generally stationary at $10 \%$. The other disagreements recorded between the test procedures were in respect of narrow monetary base and private sector credit under which the ADF suggested I(0) but the PP indicated I(1) for the cyclical components generated using the HP filter. All data series were in natural log. 
Table 1. Unit root tests

\begin{tabular}{|c|c|c|c|c|c|}
\hline \multirow{3}{*}{ Cycle $/ 2^{\text {nd }}$ Difference } & \multicolumn{4}{|c|}{ Test Type } & \multirow{3}{*}{ Remark } \\
\hline & \multicolumn{2}{|c|}{ Augmented Dickey-Fuller (ADF) } & \multicolumn{2}{|c|}{ Phillips-Perron (PP) } & \\
\hline & Level & $1^{\text {st }}$ Difference & Level & $1^{\text {st }}$ Difference & \\
\hline BPFINF & $-6.66(0.00)$ & - & $-10.55(0.00)$ & - & $\mathrm{I}(0)$ \\
\hline HPCINF & $-6.79(0.00)$ & - & $-9.11(0.00)$ & - & $\mathrm{I}(0)$ \\
\hline BPFIMP & $-6.51(0.00)$ & - & $-20.31(0.00)$ & - & $\mathrm{I}(0)$ \\
\hline HPCFIMP & $-6.46(0.00)$ & - & $-6.45(0.00)$ & - & $\mathrm{I}(0)$ \\
\hline BPFRIR & $-6.95(0.00)$ & - & $-10.50(0.00)$ & - & $\mathrm{I}(0)$ \\
\hline HPCFRIR & $-5.63(0.00)$ & - & $-4.47(0.00)$ & - & $\mathrm{I}(0)$ \\
\hline BPFYCUT & $-6.75(0.00)$ & - & $-5.38(0.00)$ & - & $\mathrm{I}(0)$ \\
\hline HPCFYCUT & $-3.29(0.07)$ & $-6.30(0.00)$ & $-3.45(0.05)$ & $-7.32(0.00)$ & $\mathrm{I}(0) @ 10 \%$ \\
\hline BPFLRIR & $-6.10(0.00)$ & - & $-8.47(0.00)$ & - & $\mathrm{I}(0)$ \\
\hline HPCLRIR & $-5.83(0.00)$ & - & $-4.94(0.00)$ & - & $\mathrm{I}(0)$ \\
\hline BPFDY & $-6.06(0.00)$ & - & $-9.02(0.00)$ & - & $\mathrm{I}(0)$ \\
\hline HPCDY & $-5.49(0.00)$ & - & $-4.57(0.00)$ & - & $\mathrm{I}(0)$ \\
\hline BPFGEX & $-7.20(0.00)$ & - & $-15.89(0.00)$ & - & $\mathrm{I}(0)$ \\
\hline HPCGEX & $-4.33(0.00)$ & - & $-4.33(0.00)$ & - & $\mathrm{I}(0)$ \\
\hline BPFGREV & $-5.41(0.00)$ & - & $-13.24(0.00)$ & - & $\mathrm{I}(0)$ \\
\hline HPCGREV & $-4.50(0.00)$ & - & $-4.58(0.00)$ & - & $\mathrm{I}(0)$ \\
\hline BPFIIO & $-6.11(0.00)$ & - & $-10.20(0.00)$ & - & $\mathrm{I}(0)$ \\
\hline HPCIIO & $-4.98(0.00)$ & - & $-4.94(0.00)$ & - & $\mathrm{I}(0)$ \\
\hline BPFTTDY & $-6.38(0.00)$ & - & $-28.16(0.00)$ & - & $\mathrm{I}(0)$ \\
\hline HPCFTTDY & $5.21(1.00)$ & $0.20(0.99)$ & $-8.58(0.00)$ & - & \\
\hline $2^{\text {nd }}$ Difference & \multicolumn{2}{|c|}{$-5.90(0.00)$} & & & $\mathrm{I}(2)$ \\
\hline BPFCPI & $-6.66(0.00)$ & - & $-10.55(0.00)$ & - & $\mathrm{I}(0)$ \\
\hline HPCCPI & $-6.79(0.00)$ & - & $-9.11(0.00)$ & - & $\mathrm{I}(0)$ \\
\hline BPFM1 & $-3.96(1.00)$ & $-0.37(0.98)$ & $3.82(1.00)$ & $-1.59(0.77)$ & \\
\hline $2^{\text {nd }}$ Difference & \multicolumn{2}{|c|}{$-8.87(0.00)$} & \multicolumn{2}{|c|}{$-9.01(0.00)$} & $\mathrm{I}(2)$ \\
\hline HPCM1 & $-4.36(0.00)$ & - & $-3.90(0.01)$ & - & $\mathrm{I}(0)$ \\
\hline BPFM2 & $4.74(1.00)$ & $-1.33(0.86)$ & $4.15(1.00)$ & $-0.98(0.93)$ & \\
\hline $2^{\text {nd }}$ Difference & \multicolumn{2}{|c|}{$-8.46(0.00)$} & \multicolumn{2}{|c|}{$-8.51(0.00)$} & $\mathrm{I}(2)$ \\
\hline HРCM2 & $-4.81(0.00)$ & - & $-3.80(0.02)$ & - & $\mathrm{I}(0)$ \\
\hline BPFMB1 & $-5.50(0.00)$ & - & $-5.91(0.00)$ & - & $\mathrm{I}(0)$ \\
\hline HPCMB1 & $-3.85(0.00)$ & - & $-2.94(0.15)$ & $-5.88(0.00)$ & $\mathrm{I}(1)$ \\
\hline BPFNFA & $-6.67(0.00)$ & - & $-8.07(0.00)$ & - & $\mathrm{I}(0)$ \\
\hline HPCNFA & $-3.69(0.03)$ & - & $-3.57(0.04)$ & - & $\mathrm{I}(0)$ \\
\hline BPFRER & $-7.45(0.00)$ & - & $-10.63(0.00)$ & - & $\mathrm{I}(0)$ \\
\hline HPCRER & $-4.43(0.00)$ & - & $-4.21(0.00)$ & - & $\mathrm{I}(0)$ \\
\hline BPFREER & $-5.74(0.00)$ & - & $-7.46(0.00)$ & - & $\mathrm{I}(0)$ \\
\hline HPCREER & $-4.17(0.00)$ & - & $-3.39(0.00)$ & - & $\mathrm{I}(0)$ \\
\hline BPFEXDT & $-6.18(0.00)$ & - & $-9.44(0.00)$ & - & $\mathrm{I}(0)$ \\
\hline HPCEXDT & $-4.09(0.01)$ & - & $-3.49(0.05)$ & - & $\mathrm{I}(0)$ \\
\hline BPFINDT & $-6.18(0.00)$ & - & $-10.97(0.00)$ & - & $\mathrm{I}(0)$ \\
\hline HPCINDT & $-4.78(0.00)$ & - & $-4.01(0.01)$ & - & $\mathrm{I}(0)$ \\
\hline BPFTDBC & $-8.45(0.00)$ & - & $-15.27(0.00)$ & - & $\mathrm{I}(0)$ \\
\hline HPCTDBC & $-7.76(0.00)$ & - & $-18.80(0.00)$ & - & $\mathrm{I}(0)$ \\
\hline BPFOP & $-6.26(0.00)$ & - & $-10.84(0.00)$ & - & $\mathrm{I}(0)$ \\
\hline НPCOP & $-4.28(0.0)$ & - & $-4.34(0.00)$ & - & $\mathrm{I}(0)$ \\
\hline BPFOPS & $-6.76(0.00)$ & - & $-11.36(0.00)$ & - & $\mathrm{I}(0)$ \\
\hline HPCOPS & $-4.29(0.00)$ & - & $-4.32(0.00)$ & - & $\mathrm{I}(0)$ \\
\hline BPFPSC & $-5.60(0.00)$ & - & $-4.88(0.00)$ & - & $\mathrm{I}(0)$ \\
\hline HPCPSC & $-4.015(0.01)$ & - & $-2.80(0.20)$ & $-5.58(0.00)$ & $\mathrm{I}(1)$ \\
\hline BPFTOT & $-6.50(0.00)$ & - & $-10.85(0.00)$ & - & $\mathrm{I}(0)$ \\
\hline НРCTOT & $-4.68(0.00)$ & - & $-3.56(0.04)$ & - & $\mathrm{I}(0)$ \\
\hline
\end{tabular}

Source: Computed

\section{The Results and Discussion}

Table 2 below presents the significant causality test for domestic output. [5 The significant results of all variables could be obtained from the author.] 
Table 2. Domestic output

\begin{tabular}{|c|c|c|c|c|c|}
\hline \multicolumn{3}{|c|}{ BP FILTER } & \multicolumn{3}{|c|}{ HP FILTER } \\
\hline Null Hypothesis & Obs. & F-Stat.(Prob.) & Null Hypothesis & Obs. & F-Stat.(Prob.) \\
\hline FRIR, DY & \multirow{3}{*}{44} & $3.6648(0.013)$ & FRIR, DY & \multirow{3}{*}{50} & $3.3228(0.019)$ \\
\hline & & & & & \\
\hline DY, FRIR & & $0.4573(0.766)$ & DY, FRIR & & $0.5247(0.718)$ \\
\hline M1, DY & \multirow{3}{*}{42} & $2.9991(0.032)$ & M1, DY & \multirow{3}{*}{50} & $3.5170(0.014)$ \\
\hline & & & & & \\
\hline DY, M1 & & $0.0634(0.992)$ & DY, M1 & & $0.0543(0994)$ \\
\hline OP, DY & \multirow{3}{*}{44} & $2.5226(0.058)$ & M2, DY & \multirow{3}{*}{50} & $2.4999(0.057)$ \\
\hline & & & & & \\
\hline DY, OP & & $0.1021(0.981)$ & DY, M2 & & $0.0809(0.987)$ \\
\hline TOT, DY & \multirow[b]{2}{*}{44} & $2.1210(0.098)$ & OP, DY & \multirow[b]{2}{*}{50} & $2.9350(0.031)$ \\
\hline DY, TOT & & $0.4031(0.805)$ & DY, OP & & $0.2688(0.896)$ \\
\hline
\end{tabular}

Pairwise Granger Causality Tests

Sample: 19602013

Lags: 4

Note: As in the other results' table, Obs. is number of observations; F-Stat. is F Statistic; Prob. is probability.

Source: Computed

Under the BP filter, four variables unidirectionally Granger-caused domestic output. They were foreign real interest rate (FRIR), narrow money (M1), crude oil price (OP) and terms of trade (TOT). Both FRIR and M1 causalities were at 5\% while those of OP and TOT were at $10 \%$. In the case of HP filter, a similar number of causalities were recorded although broad money (M2) displaced TOT. As with the case of BP filter, the FRIR and M1 causalities were at 5\% while the M2 and OP counterparts were at $10 \%$.

In Table 3, the summary result for industrial output suggested only two Granger-causing variables under BP filter, FRIR and M1, with both established unidirectionally at 5\%. It also indicated four unidirectional Granger-causality variables for HP viz: FRIR, M1, M2 and OP with the strength of causality at 5\% for the first two and 10\% for the remainder.

Table 3. Industrial output

\begin{tabular}{|c|c|c|c|c|c|}
\hline \multicolumn{3}{|c|}{ BP FILTER } & \multicolumn{3}{|c|}{ HP FILTER } \\
\hline Null Hypothesis & Obs. & F-Stat.(Prob.) & Null Hypothesis & Obs. & F-Stat.(Prob.) \\
\hline FRIR, IIO & 44 & $3.1034(0.027)$ & FRIR, IIO & 50 & $2.8405(0.036)$ \\
\hline IIO, FRIR & & $0.2024(0.935)$ & IIO, FRIR & & $0.4848(0.746)$ \\
\hline M1, IIO & 42 & $2.7411(0.045)$ & M1, IIO & 50 & $2.9358(0.031)$ \\
\hline \multirow[t]{5}{*}{ IIO, M1 } & & $0.1071(0.979)$ & IIO, M1 & & $0.0750(0.989)$ \\
\hline & & & $\mathrm{M} 2, \mathrm{IIO}$ & 50 & $2.2162(0.084)$ \\
\hline & & & $\mathrm{IIO}, \mathrm{M} 2$ & & $0.1058(0.979)$ \\
\hline & & & OP, DY & 50 & $2.2390(0.081)$ \\
\hline & & & DY, OP & & $0.2212(0.925)$ \\
\hline
\end{tabular}

Pairwise Granger Causality Tests

Sample: 19602013

Lags: 4

Source: Computed

The grounds common to both filters in the case of domestic output were FRIR, M1 and OP while in the case of industrial output, they were FRIR and M1.

The three principal components of this result were as follows. Firstly, monetary policy cycles principally, cycles of the narrow money supply drove cycles of domestic output and domestic industrial productions. Secondly, the effect of exogenous factors could be separated into two: (1) cycles of policy factors e.g. foreign real interest rate that in this study explained the cycles of the two domestic productions, and, (2) cycles of trade linked factors e.g. crude oil price and terms of trade that explained the cycles of domestic output as well as some transmission channels such as: narrow monetary base and net foreign assets in the case of oil price, and, narrow monetary base; government revenue, openness and foreign real interest rate in the case of terms of trade. Thirdly, no cycle associated with fiscal policy or the technology terrain could explain cycles of domestic output and/or of domestic industrial productions. [6 There were evidences though that at lower lag frequencies precisely 1 to 3, causalities occurred between government expenditure and GDP on the one 
hand and between government expenditure and industrial output on the other. However, whereas the causality at lag 1 was of the order of both output measures driving government expenditure, the lag 2 causalities were bidirectional; also, a unidirectional causality running from government expenditure to industrial productions was recorded at lag 3. For contrast, at lags 2 and 3, narrow money consistently and unidirectionally granger-caused both output measures. Therefore, given the absence of a clear-cut 'driving order' in the fiscal arena, in particular, the complete absence of causality between government revenue and the output measures as well as between the measures of fiscal impulse and domestic output, the outcome of any stabilization policy predicated on fiscal policy would be uncertain and such a step, clearly illinformed.]

The outcome of the impact of the monetary policy cycles appeared to be a strong case for a rule-based monetary policy. Thus, as canvassed by the Monetarists and endorsed by the New Classical Macroeconomic School, a simple rule of constant narrow money growth could be beneficial to the stability of output and industrial productions. [7 As suggested by Monetarists, the money growth rule could be adjusted for past velocity changes should demand for money function turned out to be unstable.] It should be noted that as narrow money consisted in part of currency and transfer payments, an imputation of some exogeneity orientations to its variations might not be far-fetched.

Interest rates in industrial countries were known to be procyclical calling for a countercyclical interest rate policy in the domestic economy especially whenever industrial countries are experiencing economic expansion. The idea would be to reduce the real cost of capital in the domestic economy. [ 8 Where the domestic economy is also simultaneously experiencing economic expansion, it might be counter-intuitive to attempt restraining the growth of domestic interest rate; in such a situation, price level changes would be the surest means of dampening the real cost of capital.] Such a policy could be supplemented by a conservative fiscal impulse that would be necessary to tackle the effect of the cycles relating to crude oil price and terms of trade. On the one hand, a conservative fiscal impulse would tend to reduce the direct impact of cycles of oil price and terms of trade on policy instruments while on the other hand, it would generate fiscal savings in good times on two fronts: a conservative oil price benchmark for budget estimates and a generally reduced propensity to spend. Such savings would provide a fiscal buffer in periods of recession such that, fiscal arrangements inherited from the booming economy would be less threatened in recession. On its own however, fiscal policy appeared to be unimportant within the context of business cycle drivers in the country.

The outcome of the impact of cycles of technology could imply that short run technological changes or minor technological changes were not strong enough to constitute source(s) of shift in the short run aggregate supply curve of the economy. Alternatively and perhaps more plausibly, the fitted output series used to proxy minor technological changes in the country was a long run variable and might have smoothen the short run variations (shocks) in aggregate supply that were very pertinent to this kind of study. This would appear to supply a basis for further research on the subject.

\section{Conclusion}

This study had been concerned with key determinants of business cycles in Nigeria. It produced the result that monetary policy cycle and the cycles linked with exogenous disturbances of different varieties were the principal drivers of cycles of domestic output and industrial productions in the country. It was however recognized in the study that some of its outcome might have been influenced by the nature of the data employed. Thus, further studies on this subject might yield new insights.

Finally, although the study was focused on a single country, its methodology, findings and implications could be of relevance to other open economies especially, those with relatively large external sectors or whose export production and structure are dominated by mineral (oil).

\section{Abbreviations}

$\mathrm{BPF}=$ Baxter-King's band-pass filter; HPC $=$ Business cycle corresponding to Hodrick-Prescott filter; $\mathrm{CPI}=$ Consumer price index $(2005=100)$; FIMP $=$ Fiscal impulse measured as the ratio of government expenditure to government revenue; FRIR $=$ Foreign real interest rate computed as the average 6 months deposit rate for USA, UK, Germany, Italy, Netherlands, France, Japan and Switzerland; LRIR = Domestic real interest rate; DY = Domestic output (GDP); FYCUT = Industrial or foreign countries' output at current prices; GEX = Government Expenditure; GREV = Government revenue; IIO = Index of domestic industrial output $(2005=100)$; FTTDY = Fitted income series [9 From a regression of time on nominal gross domestic product.]; INF = Domestic inflation computed as logarithmic change in CPI; M1 = Narrow money supply; M2 = Broad money supply; MB1 = Narrow monetary base; NFA = Net foreign assets; RER = 
Unweighted multilateral real exchange rate (average of five countries' RER); REER = Geometrically weighted multilateral real exchange rate [10 The statistics of the eight countries named in the text were used in the computation.]; EXDT = External debt; INDT = Internal debt; TDBC $=$ Trade balance; $\mathrm{OP}=$ Crude oil price; OPS = Openness; $\mathrm{PSC}=$ Private sector credit, and, TOT $=$ Terms of trade.

\section{References}

[1] World Bank. World Development Indicators. Washington DC: The World Bank; 2019.

[2] Kydland F, Prescott E. Time to build and aggregate fluctuations. Econometrica 1982; 50(6): 1345-1370.

[3] Ogun O. Output fluctuations in Nigeria. Economia Internazionale/International Economics 2018; 71(4): 465-502.

[4] Summers L. Some sceptical observations on real business cycle theory. Federal Reserve Bank of Minneapolis Quarterly Review 1989; 10(4): 23-27.

[5] Friedman M. The role of monetary policy American Economic Review 1968; 58(1): 1-17.

[6] Friedman M, Schwartz AJ. A Monetary History of the United States, 1867 to 1960. Princeton NJ: Princeton University Press; 1963.

Friedman M, Schwartz A, Money and business cycles. In: National Bureau Committee for Economic Research (ed.) The State of Monetary Economics. Boston: National Bureau of Economic Research, Boston; 1965; pp. 32-78.

[7] Jahan S, Papageorgiou C. What is Monetarism? Finance and Development 2014; 51(1): 38-39.

[8] McGrattan E. The macroeconomic effects of distortionary taxation. Journal of Monetary Economics 1994; 33(3): $573-$ 601.

[9] Gordon R. What is New-Keynesian economics? Journal of Economic Literature 1990; 28(3): 1115-1171.

[10] Knotec E II. A tale of two rigidities: Sticky prices in a sticky-information environment. Journal of Money, Credit and Banking 2010; 42(8): 1543-1564.

[11] Ando A, Modigliani F. The relative stability of monetary velocity and investment multipliers. American Economic Review 1965; 55(4): 693-728.

[12] Andersen L, Jordan J. Monetary and fiscal actions: A test of their relative importance in economic stabilization. Federal Reserve Bank of St. Louis Review 1968; 50, (November): 11-23.

[13] Mendoza E. The terms of trade, the real exchange rate, and economic fluctuations. International Economic Review 1994; 36(1): 101-137.

[14] Easterly W. The lost decade: Explaining developing countries' stagnation in spite of policy reform, 1980 - 1998. Journal of Economic Growth 1999; 6(2): 135-157.

[15] Plosser C. Understanding real business cycle. Journal of Economic Perspectives 1989; 3(3): 51-77.

[16] Prescott E. Theory ahead of business cycle measurement. Federal Reserve Bank of Minneapolis Quarterly Review 1986; 10(4): 9-22.

[17] Granger C. Investigating causal relations by econometric models and cross-spectral method. Econometrica 1969; 37(3): 424-438. 